\title{
Tripled coincidence and common fixed point theorems for hybrid pair of mappings
}

\section{AbDul Rahim KHAN, Mujahid AbBas and Basit Ali}

\section{ABSTRACT.}

The tripled fixed point is a generalization of the well known concept of "coupled fixed point". In this paper, we establish tripled coincidence and tripled common fixed point theorems for a hybrid pair consisting of a multi-valued and a single valued mapping on a metric space. We give examples to illustrate our results.

Acknowledgement. The authors A. R. Khan and M. Abbas are grateful to King Fahd University of Petroleum and Minerals for supporting research project IN 101037.

\section{REFERENCES}

[1] Abbas, M., Khan, M. A. and Radenović, S., Common coupled fixed point theorems in cone metric spaces for w-compatible mappings , Appl. Math. Comput., 217 (2010), 195-202

[2] Abbas, M., Aydi, H. and Karapinar, E., Tripled fixed points of multivalued nonlinear contraction mappings in partially ordered metric spaces, Abstract Applied Anal., 2011, Article ID 812690

[3] Al-Thagafi, M. A. and Shahzad, N., Coincidence points, generalized I- nonexpansive multimaps and applications, Nonlinear Anal., 67 (2007), No. $7,2180-2188$

[4] Altun, I., Damjanović, B. and Djorić, D., Fixed point and common fixed point theorems on ordered cone metric spaces, Appl. Math. Lett., 23 (2010), 310-316

[5] Aydi, H. and Karapinar, E., Tripled fixed points in ordered metric spaces, Bull. Math. Anal. Appl., 4 (2012), No. 1, 197-207

[6] Aydi, H., Karapinar, E. and Shatanawi, W. A., Tripled fixed point results in generalized metric spaces, J. Applied Math., 2012 (2012), Article ID 314279

[7] Berinde, V., Some remarks on a fixed point theorem for Ciric-type almost contractions, Carpathian J. Math., 25 (2009), No. 2, 157-162

[8] Berinde, V. and Borcut, M., Tripled fixed point theorems for contractive type mappings in partially ordered metric spaces, Nonlinear Anal., 74 (2011), 4889-4897

[9] Bhashkar, T. G. and Lakshmikantham, V., Fixed point theorems in partially ordered metric spaces and applications, Nonlinear Anal., 65 (2006), 1379-1393

[10] Dhage, B. C., A fixed point theorem for multi-valued mappings on ordered Banach spaces with applications, Nonlinear Analysis Forum, 10 (2005), 105-126

[11] Dhage, B. C., A general multi-valued hybrid fixed point theorem and perturbed differential inclusions, Nonlinear Anal., 64 (2006), 2747-2772

[12] Dhage, B. C., Hybrid fixed point theory for strictly monotone increasing multi-valued mappings with applications, Comput. Math. Appl., 53 (2007), 803-824

[13] Dube, L. S., A theorem on common fixed points of multi-valued mappings, Ann. Soc. Sci. Bruxelles, 89 (1975), 463-468

[14] Gordji, M. E., Baghani, H., Khodaei, H. and Ramezani, M., A generalization of Nadler's fixed point theorem, J. Nonlinear Sci. Appl., 3 (2010), No. $2,148-151$

[15] Hardy, G. E. and Rogers, T. D., A generalization of a fixed point theorem of Reich, Canad Math Bull., 16 (1973), 201-206

[16] Hong, S., Fixed points of discontinuous multivalued increasing operators in Banach spaces with applications, J. Math. Anal. Appl., 282 (2003), 151-162

[17] Hong, S., Fixed points for mixed monotone multivalued operators in Banach spaces with applications, J. Math. Anal. Appl., 337 (2008), 333-342

[18] Hong, S., Guan, D. and Wang, L., Hybrid fixed points of multivalued operators in metric spaces with applications, Nonlinear Anal., 70 (2009), 4106-4117

[19] Hong, S., Fixed points of multivalued operators in ordered metric spaces with applications, Nonlinear Anal., 72 (2010), 3929-3942

[20] Khan, A. R., Domlo, A. A. and Hussain, N., Coincidences of Lipschitz type hybrid maps and invariant approximation, Numer. Funct. Anal. Optimiz., 28 (2007), No. (9-10) 2180-2188

[21] Klim, D. and Wardowski, D., Fixed point theorems for set-valued contractions in complete metric spaces, J. Math. Anal. Appl., 334 (2007), 132-139

[22] Lakshmikantham, V. and Ćirić, L., Coupled fixed point theorems for nonlinear contractions in partially ordered metric space, Nonlinear Anal., 70 (2009), 4341-4349

[23] Luong, N. V. and Thuan, N. X., Coupled fixed points in partially ordered metric spaces and application, Nonlinear Anal., 74 (2011), $983-992$

[24] Markin, J. T, Continuous dependence of fixed point sets, Proc. Amer. Math. Soc., 38 (1973), 545-547

[25] Nadler, S. B., Multi-valued contraction mappings, Pacific J. Math., 20 (1969), 475-488

[26] Reich, S., Kannan's fixed point theorem, Boll Un Mat Ital., 4 (1971), 1-11

[27] Reich, S., Fixed points of contractive functions, Boll Un Mat Ital., 5 (1972), 26-42

[28] Sabetghadam, F., Masiha, H. P. and Sanatpour, A. H., Some coupled fixed point theorems in cone metric space, Fixed Point Theory Appl., (2009), Article ID 125426

[29] Samet, B., Coupled fixed point theorems for a generalized Meir-Keeler contraction in partially ordered metric spaces, Nonlinear Anal., 72 (2010), $4508-$ 4517

[30] Samet, B. and Vetro, C., Coupled fixed point theorems for multi-valued nonlinear contraction mappings in partially ordered metric spaces, Nonlinear Anal., 74 (2011), 4260-4268

[31] Sedghi, S., Altun, I. and Shobe, N., Coupled fixed point theorems for contractions in fuzzy metric spaces, Nonlinear Anal., 72 (2010), 1298-1304

Received: 12.07.2012; In revised form: 15.11.2012; Accepted: 20.11.2012

2010 Mathematics Subject Classification. 47H10, 47H04, 47H07.

Key words and phrases. Tripled coincidence point, tripled fixed point, w-compatible mappings, F-weakly commuting mappings. 
Department of Mathematics and Statistics

King Fahd University of Petroleum and Minerals

DHAHRAN, 31261, SAUDI ARABIA

E-mail address: arahim@kfupm. edu.sa

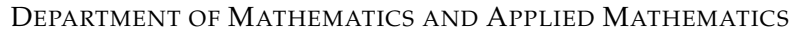

UNIVERSITY OF PRETORIA

LYNNWOOD ROAD, Preotia 0002, SOUTH Africa

E-mail address: mujahidelums.edu.pk

DepartMENT OF MATHEMATICS

LAHORE UNIVERSITY OF MANAGEMENT SCIENCES

LAHORE, 54792, PAKISTAN

E-mail address: basit.aa@gmail.com 